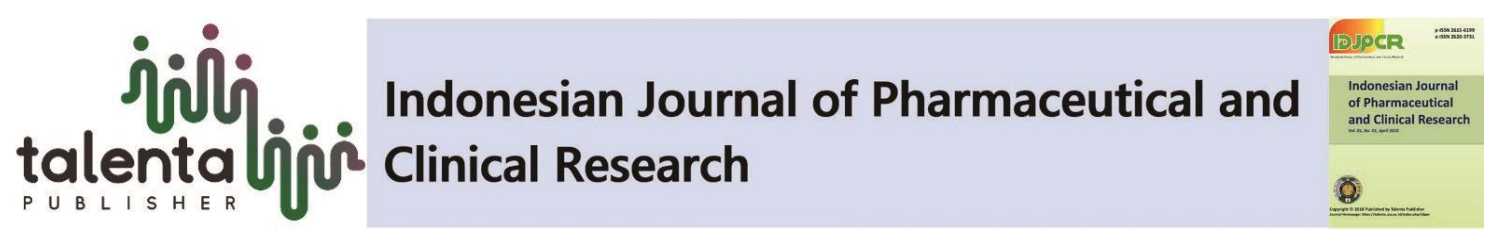

\title{
The Effctiveness Of Angiotensin Receptor Neprilysin Inhibitor On Improving The Cardiac Remodelling Compared To Ace-Inhibitor On Patients With Chronic Heart Failure
}

\author{
Muhammad Sobri Maulana \\ Medical Profession, Faculty of Medicine, University of Indonesia, Jakarta
}

\begin{abstract}
Heart failure is one of the major cause of patient's admittance to the hospital. Primary hypertension is one of the most universal comorbidities that precedes heart failure and is one of the more common risk factors held by the majority of the population. Right now, antihypertension that are generally used is from AngiotensinConverting Enzyme Inhibitor (ACE-I) and Angiotensin Receptor Blocker (ARB). A new group of an antihypertensive agent called "Angiotensin Receptor Neprilysin Inhibitor (ARNI)" to further improve the patient condition. This study aims to evaluate the effectivity of ARNI against ACE-I regarding its cardiac reverse remodeling effect. Search strategy was done using electronic databases, which are Pubmed, Scopus, and Cochrane. Articles included are therapeutic study that is in line with the clinical question and fulfills the inclusion and exclusion criteria. Critical appraisal was done by assessing the article's validity, importance, and applicability according to Oxford Center of Evidence-Based Medicine 2011 to two chosen articles. 2 articles are chosen and appraised. Both of the study are shown to be valid and shows that ARNI has a significantly better result on improving cardiac reverse remodeling via the left ventricle ejection fraction compared to ACE-I. However, the applicability of ARNI is still debatable in Indonesia as it was not covered by national insurance and there is no generic form. ARNI shows to be significantly better to reverse cardiac remodeling compared to ACE-I, but its applicability has to be improved to be implemented in Indonesia.
\end{abstract}

Keywords: ACEI, ARNI, Effectiveness, Heart Failure

\begin{abstract}
Abstrak. Gagal jantung merupakan salah satu penyebab utama pasien masuk rumah sakit. Hipertensi primer adalah salah satu komorbiditas paling universal yang mendahului gagal jantung dan merupakan salah satu faktor risiko yang umum dipegang oleh sebagian besar populasi. Saat ini antihipertensi yang banyak digunakan adalah dari Angiotensin-Converting Enzyme Inhibitor (ACE-I) dan Angiotensin Receptor Blocker (ARB). Sekelompok baru agen antihipertensi yang disebut "Angiotensin Receptor Neprilysin Inhibitor (ARNI)" untuk lebih meningkatkan kondisi pasien. Penelitian ini bertujuan untuk mengevaluasi efektivitas ARNI terhadap ACE-I terkait efek remodeling balik jantung. Strategi pencarian dilakukan dengan menggunakan database elektronik yaitu Pubmed, Scopus, dan Cochrane. Artikel yang termasuk adalah studi terapeutik yang sejalan dengan pertanyaan klinis dan memenuhi kriteria inklusi dan eksklusi. Penilaian kritis dilakukan dengan menilai validitas,
\end{abstract}

\footnotetext{
*Corresponding author at: Faculty of Medicine, University of Indonesia, Jakarta

E-mail address: muhammadsobrimaulana31@gmail.com
} 


\begin{abstract}
kepentingan, dan penerapan artikel menurut Oxford Center of Evidence-Based Medicine 2011 untuk dua artikel yang dipilih. 2 artikel dipilih dan dinilai. Kedua penelitian tersebut terbukti valid dan menunjukkan bahwa ARNI memiliki hasil yang jauh lebih baik dalam meningkatkan remodeling balik jantung melalui fraksi ejeksi ventrikel kiri dibandingkan dengan ACE-I. Namun, penerapan ARNI masih diperdebatkan di Indonesia karena tidak tercakup oleh asuransi nasional dan tidak ada bentuk generiknya. ARNI menunjukkan jauh lebih baik untuk mengembalikan remodeling jantung dibandingkan dengan ACE-I, tetapi penerapannya harus ditingkatkan untuk diterapkan di Indonesia.
\end{abstract}

Kata kunci: ACEI, ARNI, Efektivitas, Gagal Jantung

Received 10 January 2021 | Revised 20 April 2021 | Accepted 28 April 2021

\title{
I. Introduction
}

Heart failure is one of the most common chronic health problem that could be faced around the world, and one the major cause of patient's admittance to the hospital. Until now, heart failure still has an immense morbidity and mortality level, whether it's in a developed or developing country, which includes Indonesia. According to a study by Bui A, et al and Vos T, et al, there are $37.7 \%$ of the world population that suffers from heart failure.[1,2]

In the US alone, there are 5.7 million cases of heart failure in 2011, and there are 870.000 new cases each year [3,4] while in Indonesia, Riset Kesehatan Dasar in 2018 shows that the prevalence of diagnosed heart disease was $1.5 \%$ of the population [5]. Chronic heart failure is a condition where the heart lost its ability to function normally. The inability to pump blood from the heart to the body and lungs cause several manifestations, such as dyspnea and edema, although these symptoms were not specifics to this particular condition. The accumulation of symptoms can be caused by the anatomical changes in the heart, which can be irreversible.[6] Heart failure could be influenced by various risk factors. Several distinct factors are diet, physical activity, and other metabolic conditions, for instances like dislipidemia, diabetes mellitus, and hypertension.[7]

Primary hypertension is one of the most universal comorbidities that precedes heart failure and is one of the more common risk factors held by the majority of the population. High blood pressure itself could lead to hypertensive heart disease, a group of disorders encompasses the complication of hypertension. Hypertension could increase the risk of heart failure development through increasing the heart's workload and causing left ventricular hypertrophy. As such, hypertension and heart failure are almost always interconnected and cannot be separated. [6,7]

To control hypertension, the primary intervention that could be done is through dietary control and increasing physical activity, but it is not uncommon to use medication as a primary modality to control hypertension. Right now, antihypertension that are generally used is from Angiotensin-Converting Enzyme Inhibitor (ACE-I), Angiotensin Receptor Blocker (ARB). Calcium Channel Blocker (CCB), Beta Blocker (BB), and diuretics. These groups of medication 
can be used as a single or combine treatment for hypertension, although usually, the first line used is ACE-I and ARB. [6,7]

This evidence-based case report will try to highlight the effectivity of a new group "Angiotensin Receptor Neprilysin Inhibitor (ARNI)" to control hypertension in patients with chronic heart failure. As a new group of drug, ARNI works by inhibiting neprilysin, a neutral endopeptidase compound that takes part in the degradation of a vasoactive peptide-like natriuretic peptide and adrenomedullin. [8] By inhibiting neprilysin, the level of vasoactive peptides will increase, thus causing vasodilatation and decreasing the extracelullar volume through the excretion of natrium. [9] This drug will be compared to the first line to control hypertension, which is ACE Inhibitor.

\section{Case report}

Mr. Z, 41 years old, came to the emergency ward RSCM (Cipto Mangunkusumo Hospital) with worsening shortness of breath since 3 days before admittance. Shortness of breath was felt mainly during the night and worsen with activity. The patient frequently woke up during his sleep because of the same complaint. Shortness of breath is not influenced by the position and can be felt throughout the day. Right now the patient needed an extended position to sleep comfortably. The patient has been diagnosed with congestion in his heart since a year ago in Cibinong General Hospital, and routinely visit the hospital monthly for control. A week ago, the patient was admitted to RSCM because of the same complaint.

In physical examination, the patient was found to be Compos Mentis and appeared as moderately sick. Blood pressure $123 / 74 \mathrm{mmHg}$, heart rate $118 \mathrm{x} /$ minute, respiratory rate $28 x /$ minute. In the facial examination, sclera was found anicteric but the conjunctiva was pale. JVP was $5+1 \mathrm{~cm} \mathrm{H} 2 \mathrm{O}$, with no enlargement of the thyroid gland or lymph node. In thorax examination, an enlargement of the heart was found during the percussion of the margin of the heart, with normal sound during auscultation with no gallop or murmur. In lungs examination, the sound was vesicular-vesicular, but rales was heard in the right lung. In the abdominal examination, the abdomen looks flat, with no liver or spleen was palpable. Ballottement test and shifting dullness were negative. In the extremity, pitting oedema was found in both legs.

In laboratory examination, it was found $\mathrm{Hb}$ was $10.4 \mathrm{~g} / \mathrm{dL}$ and $\mathrm{Ht}$ 34.7. Leucocyte level was $8180 / \mathrm{mm} 3$, and thrombocyte was 331.000/mm3. MCV/MCH was 67.9/22.3. In plain imaging of the thorax, cardiomegaly with lung edema was found, with right pleural effusion.

\section{Clinical Question}


"How is The Effectiveness of Angiotensin Receptor Neprilysin Inhibitor on improving the cardiac remodeling compared to Angiotensin Receptor Blocker on patients with chronic heart failure?"

Table 1. PICO

\begin{tabular}{lllll}
\hline PICO & Population & Intervention & Comparison & Outcome \\
\cline { 2 - 5 } & Patients with & Angiotensin & Angiotensin- & Cardiac \\
& $\begin{array}{l}\text { Chronic Heart } \\
\text { failure }\end{array}$ & $\begin{array}{l}\text { Receptor } \\
\text { Neprilysin }\end{array}$ & $\begin{array}{l}\text { Converting } \\
\text { Enzyme }\end{array}$ & $\begin{array}{l}\text { Reverse } \\
\text { Remodelling } \\
\end{array}$ \\
Inhibitor & Inhibitor & (LVEF) \\
Clinical & Treatment & & \\
Aspect & & & \\
Study Design & Meta-analysis, systematic review, clinical trial, RCT & \\
\hline
\end{tabular}

\section{Methods}

\subsection{Research Strategy}

The literature search was used to identifying relevant study using 3 electronic databases, which is Pubmed, Cochrane, and Proquest. Keywords used are the combination of "Chronic heart failure", "Angiotensin Receptor Neprilysin Inhibitor", “Angiotensin- Converting Enzyme Inhibitor", and "Cardiac Remodelling" with their matching equivalent that is combined using Boolean operation (Table 1). The search strategy from each of the database is not restricted with any specific limitation

Tabel 2 Search strategy on 3 databases and articles chosen.

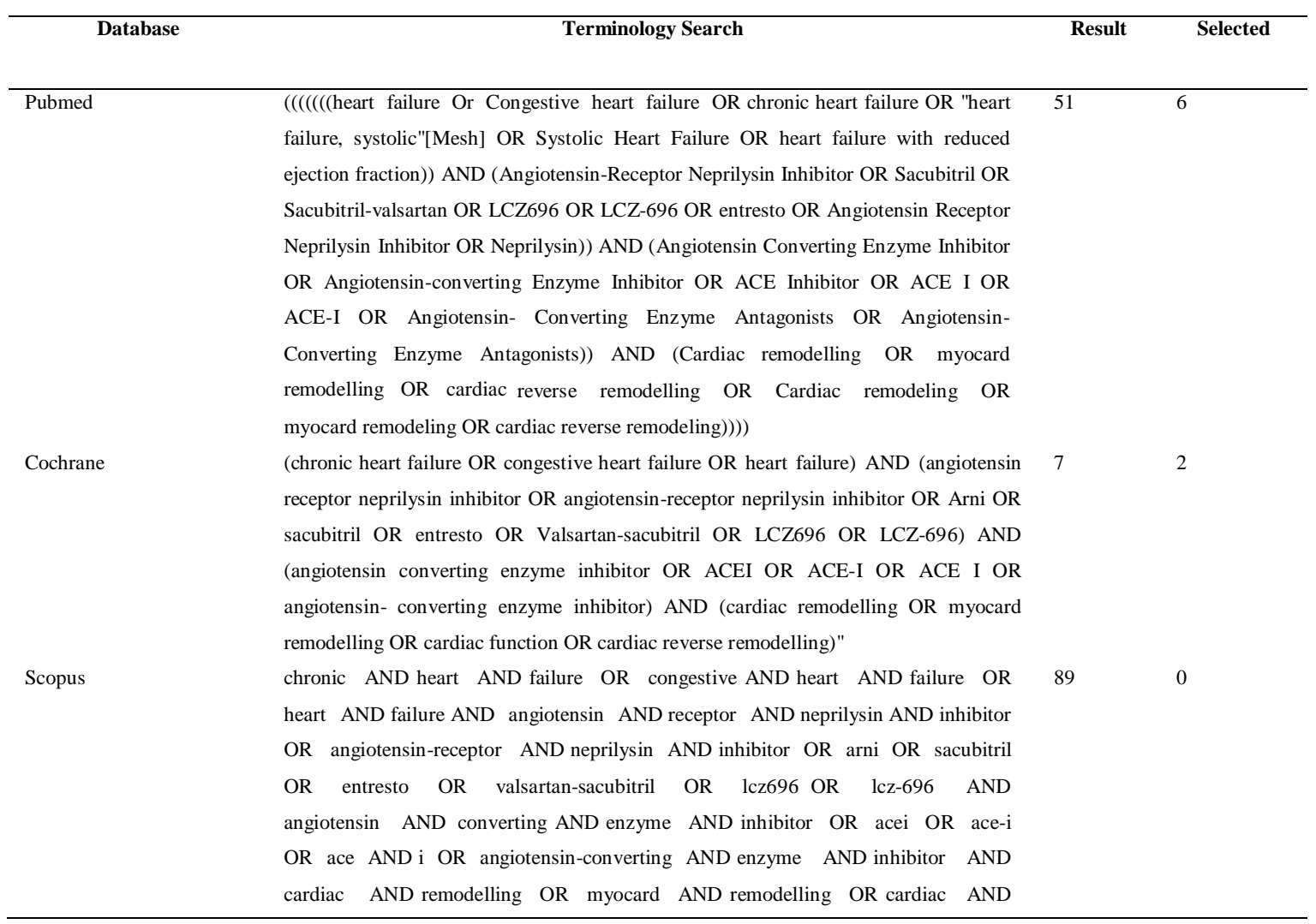




\subsection{Article Selection}

Table 2 concludes the process of article selection. The total articles found from 3 databases are 147 articles. The process of selecting the articles was done through these steps: 1 . Selection based on the title and abstracts, 2. Selection based on duplicated articles, 3. Selection based on the completed reading of the articles. For the first part, the selection based on the title and abstracts will be adjusted to the inclusion and exclusion criteria that have been selected before. The inclusion criteria include published therapeutic studies that use RCT, systematic review, or meta- analysis methods, have objective parameters, and relevant to our clinical question. The exclusion criteria include animal studies, known-English studies, and another disease outside of heart failure. From this inclusion and exclusion, 9 studies were found to be suitable. From these articles, duplicate articles were filtered from the databases. Articles without access to the full text were filtered and were further screened on the research relevancy with the variables listed with the clinical question. From the screening, 2 articles were deemed appropriate to be used for clinical appraisal.

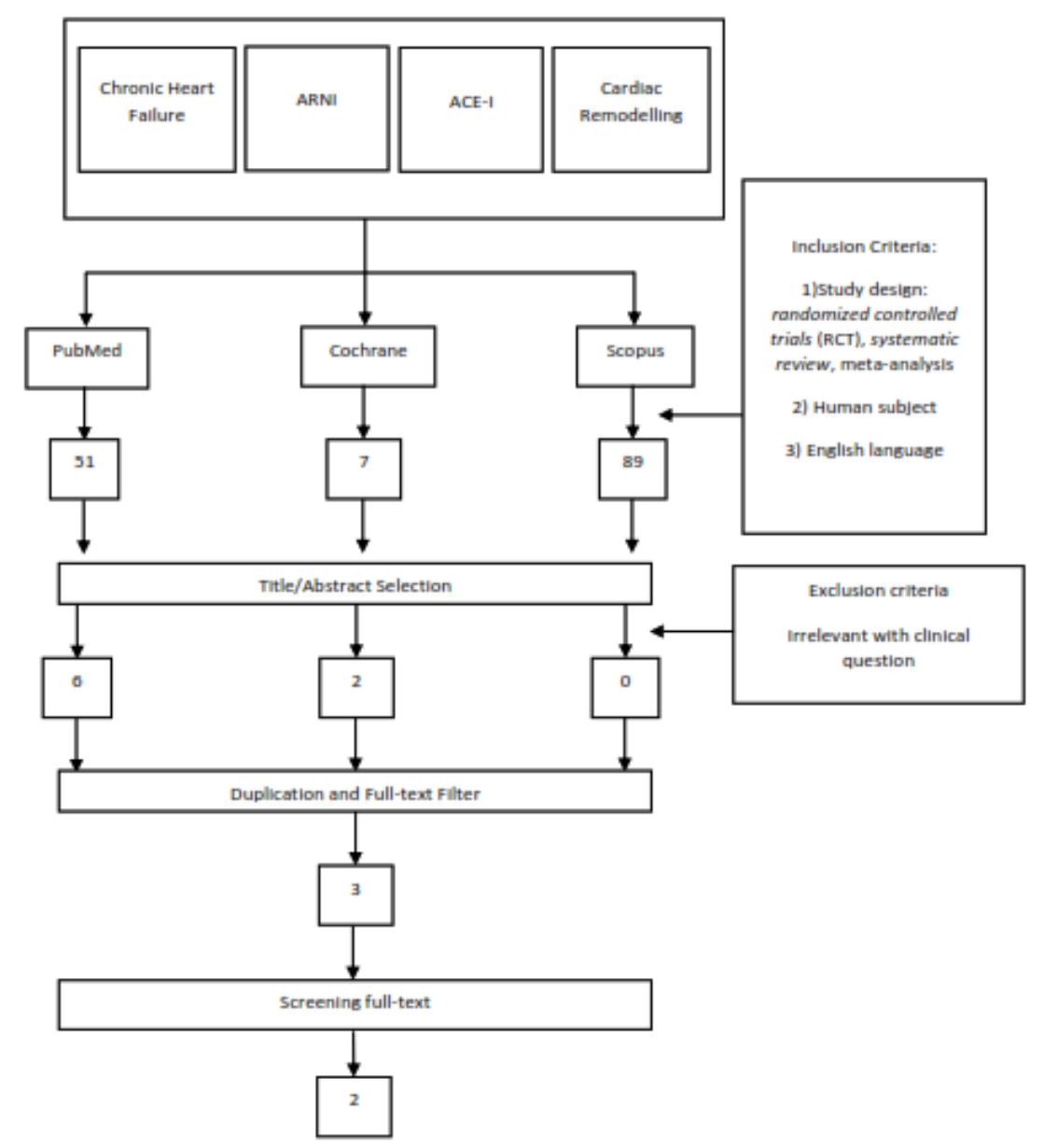




\subsection{Clinical Appraisal}

Figure 1. Article Selection Process

Articles chosen were appraised to evaluate the quality of the published articles. The appraisal was done using Oxford Center for Evidence-Based Medicine 2011 criteria that include validity, importance, and applicability aspects from said studies.

\section{Chosen Articles}

1. Wang Y, Zhou R, Lu C, Chen Q, Xu T, Li D. Effects of the AngiotensinReceptor Neprilysin Inhibitor on Cardiac Reverse Remodeling: Meta-Analysis. J Am Heart Assoc. 2019;8(13):e012272.

2. Gonzales-Torres L, De Diego C, Centurion R, Macias M, De Lara G, Carrasco R, Almendral J. Angiotensin-neprilysin inhibition further reverses cardiac remodeling as compared to angiotensin inhibition in reduced heart failure patients. Clinical Cardiology Journal Volume II. 2018

\section{Results}

\subsection{Validity}

In its validity aspect, the study from Wang et al (2019) is deemed to be valid (Table 3.). The PICO from this study showed a clear connection between its population, which is patients with heart failure with reduced ejection fraction or preserved ejection fraction, its intervention, that compares the usage of ARNI and ACE-I, and the outcome of the study which is Cardiac reverses remodeling indices (LVEF). This study used major databases for its search strategy, with clearly defined inclusion and exclusion criteria. Finally, the study was proven to be homogenous from its results.

Table 3. Critical Appraisal on validity aspect of meta-analysis Wang et al (2019)

\begin{tabular}{|c|c|}
\hline Parameter & Wang et al (2018) \\
\hline $\begin{array}{l}\text { Was the clinical question(PICO) clearly and specifically } \\
\text { defined (+) }\end{array}$ & $\begin{array}{l}\text { The PICO in this article were clear and showed a clear } \\
\text { connection between the intervention and intended outcome } \\
\text { P: Patients with heart failure with reduced ejection fraction or } \\
\text { preserved ejection fraction (HreFR or HRpFR) } \\
\text { I: Angiotensin-Receptor Neprilysin Inhibitor C: Angiotensin- } \\
\text { Converting Enzyme Inhibitors O: Cardiac reverses remodeling } \\
\text { indices (LVEF) }\end{array}$ \\
\hline Were the groups similar at the start of the trial? (+) & $\begin{array}{l}\text { In patient characteristics table, similar baseline characteristics } \\
\text { of the patients can be seen in all of the aspects, as the subjects } \\
\text { were the same }\end{array}$ \\
\hline $\begin{array}{l}\text { Aside from the allocated treatment, were groups treated } \\
\text { equally? (+) }\end{array}$ & $\begin{array}{l}\text { The patients received the same dose of medication of ACE } \\
\text { Inhibitor for } 9 \text { months, continued with ARNI for a further } 9 \\
\text { months. Echocardiography was done for every } 3 \text { months until }\end{array}$ \\
\hline
\end{tabular}


Were all patients who entered the trial accounted for? And were they analyzed in the groups to which they were randomized? (+)

Were measures objective or were the patients and clinicians kept "blind" to which treatment was being received? (-)

\section{8 months.}

All of the patients were accounted for, and no patient was loss to the follow-up

The measures were objective where the outcome measured was LVEF and LVDD using echocardiography, however, as it was a prospective study, both patients and clinicians were aware of the treatment received

\subsection{Importance}

In Wang et al study(Table 3), it was shown that there is a significant difference of cardiac reverse remodeling in ARNI and ACE-I, in which the left ventricle ejection fraction level in ACE-Inhibitor was found to be significantly lower than the one that used ARNI(p-value $<0.00001)$. This result was in line with the results from Gonzales- Torres et al study, where they use $2 \mathrm{D}$ and $3 \mathrm{D}$ echocardiography parameter to calculate the left ventricle ejection fraction. Gonzales-Torres et al also show that patients treated with ARNI have significantly better LVEF volume in comparison to the use of ACE- Inhibitor alone (p-value <0.002).

Table 4. Critical Appraisal of importance aspect of meta-analysis Wang et al (2019

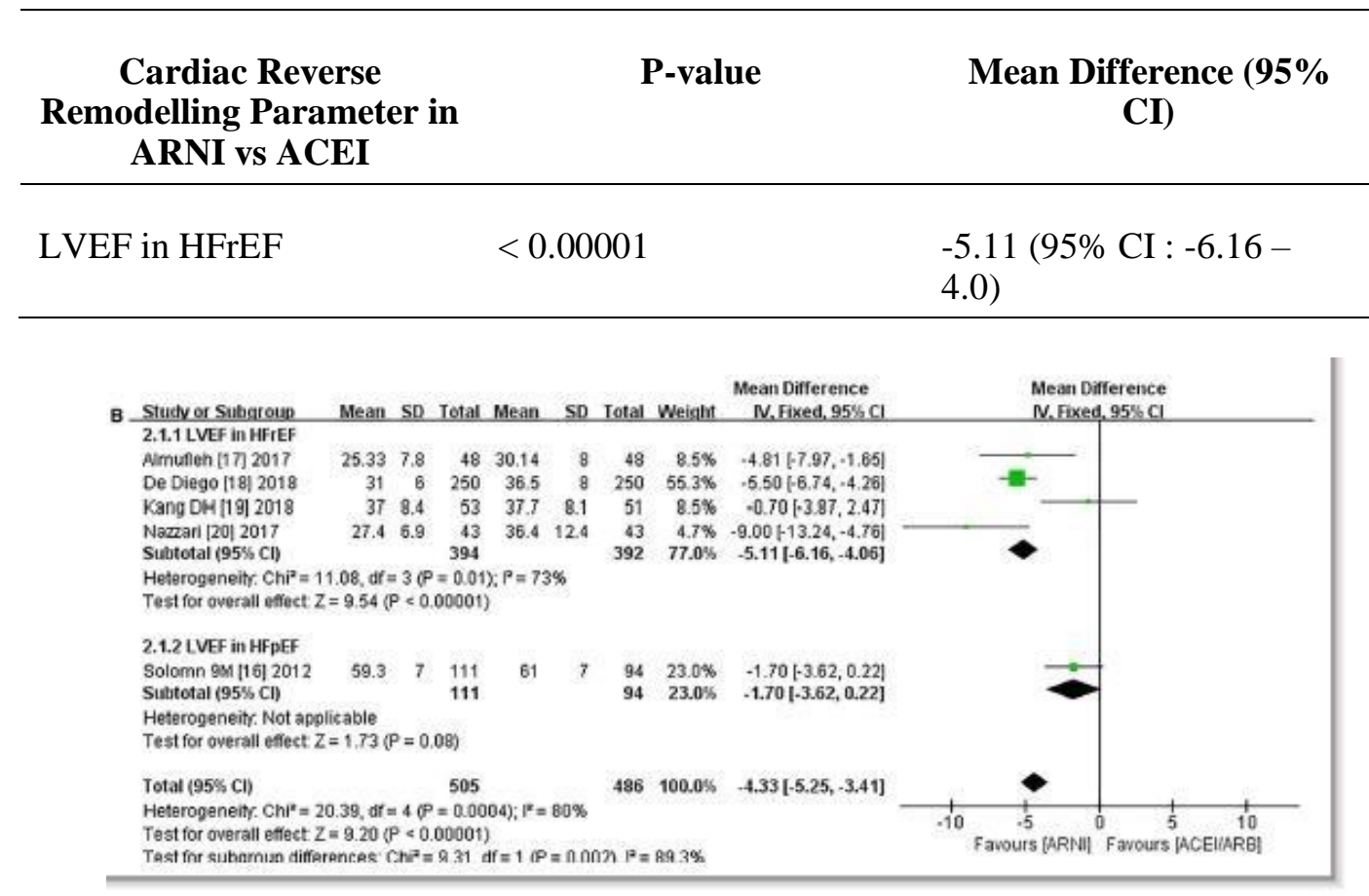

Figure 2. Forrest plot on Effectivity of ARNI against ACE-I on LVEF from Wang et al (2019)

Table 5. Critical Appraisal of importance aspect of meta-analysis Wang et al (2019) 


\begin{tabular}{ccc}
\hline $\begin{array}{c}\text { Cardiac Reverse } \\
\text { Remodelling Parameter in } \\
\text { ARNI vs ACEI }\end{array}$ & P-value & $\begin{array}{c}\text { Mean Difference (95\% } \\
\text { CI) }\end{array}$ \\
\hline LVEF in HFrEF & $<0.00001$ & $-5.11(95 \%$ CI $:-6.16-$ \\
& & $4.0)$ \\
\hline
\end{tabular}

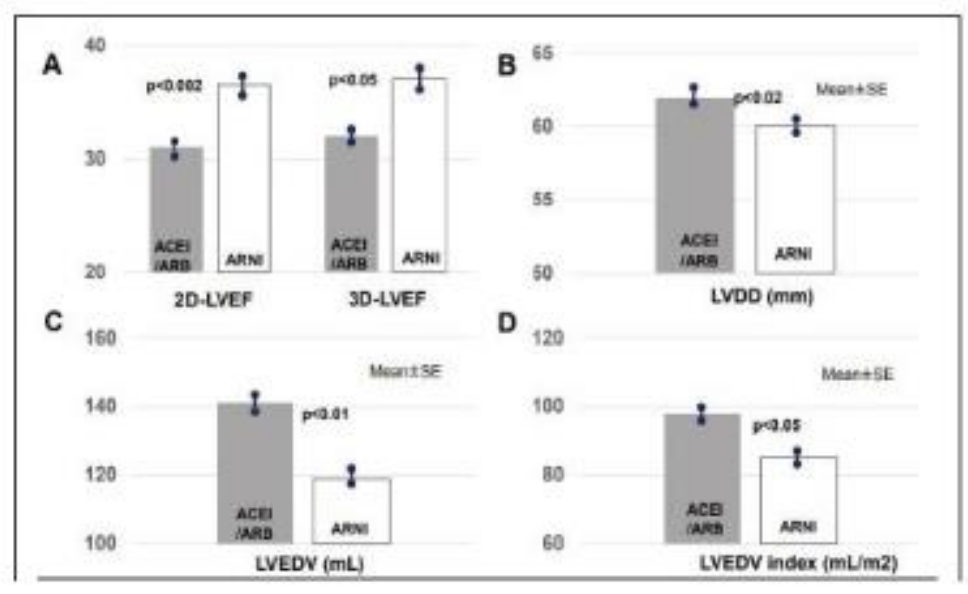

Figure 3. Sacubitril-valsartan reverse cardiac remodeling (LVEF and LV size) at 9 months as assessed by 2D and automatic 3D-echocardiogram from Gonzales-Torres et al (2018)

\subsection{Applicability}

Both of the articles are further analyzed from its applicability aspect with respect to its implementation in Indonesia. In its implementation of our case, the studies have a significantly older range of age, where in the study it was from 58-77 years old, while our patient was still 41 years old. ARNI has already been distributed in Indonesia in the form of a tablet, although its usage is still minimal in comparison to another group of drugs such as ACE Inhibitor and $\mathrm{ARB}$, as it was confined by the price and its BPJS coverage. Benefit and Harm aspect from this treatment can be said to be more beneficial as the level of left ventricle ejection fraction was significantly better in patients that took ARNI for a certain amount of time compared to those that took ACE Inhibitor alone.

Table 6. Critical Appraisal of importance aspect of meta-analysis Wang et al (2019)

\begin{tabular}{lcc}
\hline \multicolumn{1}{c}{ Parameter } & \multicolumn{1}{c}{ Wang et al (2018) } & Gonzales-Torres et al (2010) \\
\hline Similarities of research subject & The age range of patients in the & The range of age in the studyis 69 \\
with the patient. & study is 58.0 to 78.6 years, and \pm 8 years old in the first part, and \\
& $76.6 \%$ of subjects were male. In $70 \pm 8$ in the second part. $76 \%$ of \\
& our case, the patient is a male, the subjects are male. In our case,
\end{tabular}




\begin{tabular}{|c|c|}
\hline & $\begin{array}{l}41 \text { years old, which is far below the patient is a male, } 41 \text { years } \\
\text { the range } \\
\text { Population gathered for the range.Population gathered for } \\
\text { study were conducted the study were from Spain only } \\
\text { worldwide, which include the The drugs used to control our } \\
\text { Asian population and was patient blood pressure is ACE- } \\
\text { appropriate to our case } \\
\text { The drugs used to control our to the study control. } \\
\text { patient blood pressure is ACE- } \\
\text { Inhibitor, which is the same } \\
\text { group to the study control. }\end{array}$ \\
\hline $\begin{array}{l}\text { Feasibility of therapy in an } \\
\text { everyday clinical setting }\end{array}$ & $\begin{array}{l}\text { Angiotensin-Receptor Neprisylin Inhibitor has already been } \\
\text { distributed in Indonesia under the name LCZ696 or Entresto, } \\
\text { although it is still rarely used in clinical practice. LCZ96 is available } \\
\text { in the form of tablet } 50 \mathrm{mg} \text { to be consumed twice a day. In } \\
\text { Indonesia, the tablet is still fairly expensive, with the approximate } \\
\text { price of Rp. } 20.000 \text { per tablet and is not covered by BPJS and there is } \\
\text { no generic form just yet. In comparison, ACE Inhibitor such as } \\
\text { Enalapril or Ramipril is Rp500 per tablet and is covered by BPJS. As } \\
\text { such, the usage of ACE Inhibitor is much more common in } \\
\text { Indonesia. From the price and coverage perspective, ACE Inhibitor } \\
\text { can be said to be more feasible and beneficial }\end{array}$ \\
\hline Benefit of Harm & $\begin{array}{l}\text { Wang et al and Gonzales-Torres et al show that there are significant } \\
\text { changes in terms of cardiac reverse remodeling, in which ARNI is } \\
\text { able to reverse cardiac remodelling better than ACE-I, where the } \\
\text { level of left ventricle ejection fraction was significantly better in } \\
\text { patients that took ARNI for a certain amount of time. }\end{array}$ \\
\hline
\end{tabular}

\section{Discussion}

According to the aspect of validity for its critical appraisal, the meta-analysis from Wang et al (2019) and RCT from Gonzales-Torres et al (2018) can be said to be valid, although another additional study with a high level of evidence such as meta-analysis and systematic review can prove to be beneficial in this EBCR.

In the study from Wang et al (2019), no heterogeneity was found from each of its parameters, so the effect from each study and their overall effect from the parameters can be used as a valid benchmark. The study from Gonzales-Torres et al (2018) was different in that the study was a prospective study, as 250 patients were treated with the same control and intervention for 9 months using ACE-I and ARNI and were not blinded, which could decrease the level of 
validity of this study. Overall, both of the studies were deemed to be valid and can be used as a benchmark for a treatment recommendation for the illustrated case in this EBCR.

In the aspect of Importance in this EBCR, the aspect can be assessed through the level of cardiac reverse remodeling index, in which in this case was the left ventricular ejection volume. (LVEF). The intervention used was ARNI versus ACE-Inhibitor as its control. Both of the studies showed similar results. A meta-analysis from Wang et al (2019) showed that there is at least $5 \%$ of improvement of LVEF from the patients using ARNI compared to ACE-Inhibitor only, where the number is shown was proven to be statistically significant. Similarly, the study from Gonzales-Torres et al, where in 2D and 3D examination by echocardiography, there were at least 5\% of improvement of LVEF in patients treated using ARNI, which was also statistically significant. Both of the study used patients with similar characteristics, although only the study from Wang et al(2019) was multi-centered. Study from Wang et al(2019) is a meta-analysis that includes multiple studies, as such was shown to be a more reliable study.

The primary outcome of both studies was to assess the level of cardiac reverse remodeling through LVEF, however, it is important to assess the other parameter for its efficacy. Aside from LVEF, Wang et al(2019) also assessed the functional capacity of the heart through NYHA class, other CRR indices such as Left Ventricle Diastolic Diameter(LVDD), end-systolic and diastolic volume (ESV and EDV), and biomarkers in both ARNI and ACEInhibitor group. On the other hand, Gonzales-Torres et al(2018) only assess NYHA and LVDD as its additional parameters of cardiac reverse remodeling aspect. In its value, both of the studies shows a similar result where ARNI seems to be significantly better in its efficacy in comparison to ACE-Inhibitor ( $\mathrm{p}$-value $<0.05$ ). Based on that statement, it can be concluded that the usage of ARNI has a more beneficial effect compared to ACE-Inhibitor based on its parameters. The applicability aspect of heart failure treatment using ARNI should also be assessed.

The population of Wang et al (2019) study was worldwide and multicenter study, which includes Asian population, as such it can be also be implemented in Indonesia, although study with Indonesian-only population should give a higher applicability level. The dosage of ARNI or ACE-Inhibitor in the studies were not given, as such it cannot be correlated to the case illustrated in this EBCR. From its availability, ARNI has already been distributed in Indonesia under the name LCZ69 or Entresto, however, it is not yet covered by BPJS nor has a generic version, thus, the usage of ARNI is still very limited for the general population in Indonesia, especially in BPJS era.

\section{Conclusion}

Based on the critical appraisal, studies from Wang et al (2019) and Gonzales- Torres et al (2018) were deemed to be valid. The benefit of ARNI compared to ACE-Inhibitor is constant 
according to the study, where the improvement level of left ventricle eject fraction was statistically significant. The applicability of ARNI, in this case, is still debatable as it is not covered by BPJS and no generic form are widely distributed.

\section{Recommendation}

Further research specific to Indonesia population is recommended to give more precise data to be implemented to the case

\section{REFERENCES}

[1] H. T. F. G. Bui AL, "Epidemiology and risk profile of heart failure," Nature Reviews Cardiology, vol. 8, no. 1, p. 30, 2011 Jan.

[2] V. T, "Years lived with disability (YLDs) for 1160 sequelae of 289 diseases and injuries 1990-2010: a systematic analysis for the Global Burden of Disease Study 2010," The lancet, vol. 380, no. 9859, pp. 2163-2196., 2012.

[3] M. D, "Heart disease and stroke statistics-2016 update: a report from the American Heart Association," Circulation, vol. 133, no. 4, pp. e38-60, 2016.

[4] F. G. Ziaeian B, "Epidemiology and aetiology of heart failure," Nature Reviews Cardiology, vol. 13, no. 6, p. 368, 2016.

[5] Badan Penelitian dan Pengembangan Kesehatan Kementerian Kesehatan RI, Jakarta: Riset Kesehatan Dasar, 2018.

[6] G. J. H. B. Neubauer BE, "Heart Failure: Optimizing Recognition and Management in Outpatient Settings," Prim Care Clin Off Pract, vol. 45, no. 1, p. 63-79, 2018.

[7] W. H. M. J. Jorsal A, "Heart Failure: Epidemiology, Pathophysiology, and Management of Heart Failure in Diabetes Mellitus," Endocrinol Metab Clin North Am, vol. 47, no. 1, p. 117-35, 2018.

[8] G. A. Malek V, "Neprilysin inhibitors: A new hope to halt the diabetic cardiovascular and renal complications?," Biomed Pharmacother, vol. 90, p. 7529, 2017.

[9] P. M. D. R. P. J. Dargad RR, "Sacubitril/valsartan: A novel angiotensin receptor-neprilysin inhibitor," Indian Heart J, vol. 172, pp. 82-95, 2018.

[10] Z. R. L. C. C. Q. X. T. L. D. Wang Y, "Effects of the Angiotensin-Receptor Neprilysin Inhibitor on Cardiac Reverse Remodeling: Meta-Analysis," J Am Heart Assoc, vol. 8, no. 13, p. e012272, 2019.

[11] D. D. C. C. R. M. M. D. L. G. C. R. A. J. Gonzales-Torres L, "Angiotensin-neprilysin inhibition further reverses cardiac remodeling as compared to angiotensin inhibition in reduced heart failure patients," Clinical Cardiology Journal Volume II, vol. 2, 2018. 